\title{
Snap Judgment? Not So Fast: Thought, Reasoning, and Choice as Psychological Realities
}

\author{
Elliot Turiel \\ University of California, Berkeley, Calif., USA
}

Many years ago when I was a student it was frequently impressed upon us that generalizing findings from one type of situation to types too far afield was scientifically unsound. At that time, the field of psychology was also undergoing what has been termed a 'cognitive revolution,' in which human beings were increasingly viewed as engaging in thought, reasoning, and choices about the world around them. The revolution was supplanting the behaviorists' propositions of environmental determinism, the maturationists' emphasis on biological determinism, and the psychoanalysts' focus on unconscious processes. All of those schools of psychology presented a view of human functioning as non-rational or irrational and involving a lack of choice. The cognitive revolution also entailed reconsideration of the robustness of findings from laboratory experiments assessing limited phenomena.

In the contemporary scene, approximately 50 years after the cognitive revolution, it often seems that findings from small phenomena in laboratory settings are being connected to broad and sweeping assertions about human psychology. Such generalizations are made in assertions that irrationality, determinism (sometimes environmental, sometimes biological), and unconscious processes are the hallmarks of human functioning. Researchers making these assertions and generalizations derive a great deal of public exposure from the media (especially the Op-Ed section of The New York Times and its Science Section, whose reporters seem enamored with all manner of biological and evolutionary explanation), as well as from popular books written by journalists (e.g., with catchy titles like Blink [Gladwell, 2005], and The Hidden Brain [Vedantam, 2010]). The media exposure, I believe, feeds back on research enterprises because it tends to have an air of certainty, without the usual qualifications and acknowledgment of serious differences within scientific communities, and because of the rewards that scientists derive from public attention.

An illustrative example of some of this, involving a public presentation of generalizations from small phenomena in laboratory settings to broad assertions, comes from a New York Times Op-Ed [Eagleman, December 5, 2009]. Eagleman, a professor

\begin{tabular}{ll}
\hline KARGER & $\odot$ 2010 S. Karger AG, Basel \\
Fax +41 61 306 12 34 & 0018-716X/10/0533-0105\$26.00/0 \\
$\begin{array}{l}\text { E-Mail karger@karger.ch } \\
\text { www.karger.com }\end{array}$ & $\begin{array}{l}\text { Accessible online at: } \\
\text { www.karger.com/hde }\end{array}$
\end{tabular}


of neuroscience, discussed US President Barack Obama's decision, announced on December 1, 2009, to send 30,000 more American troops to Afghanistan, with a deadline of 18 months for the start of troop withdrawal. As is well known, US involvement in the war in Afghanistan began with an invasion in October of 2001, after the terrorist attacks of September 11,2001. The eight-plus-year history of this war includes the war in Iraq that many believe detracted from the war in Afghanistan.

Eagleman [2009] predicted how the deadline of 18 months would 'affect the psychology of the nation' (p. A33). Focusing on the emotional effect of the deadline, he drew on a few experiments presenting people with different deadlines, which presumably make for differing levels of certainty. One posed participants with an offer of USD 100 right now or USD 110 a week from now. Most chose the USD 100 (and presumably offering USD 100 now and USD 500 in 18 months would produce the same result). In other studies using brain imaging when people made similar decisions it was discovered that the neural networks in short- and long-term decisions are fundamentally separate (' $\ldots$ often locked in battle against one another' [Eagleman, 2009, p. A33]). According to Eagleman, these experiments tell us a great deal about how people will react to Obama's decisions on Afghanistan, including that a timetable of 18 months is too long, that the President would better serve his purposes with intermediate goals that would provoke emotions in people, and that because of the long-term deadline people would ignore what occurs in the short term.

Therefore, the findings from experiments on decisions about obtaining money in experimental situations supposedly tell us about issues having to do with life and death, national security, putting young people in situations in which they could be killed or seriously harmed, occupying another country with troops, questions of when and how to extricate from the war, and the financial hardships of committing to war in the midst of a severe recession and high unemployment. All this occurred in the context of fears of terrorism, mixed results in continuing wars on two fronts, and the well-known experiences of a quagmire in the Vietnam War.

Eagleman [2009] presumes that people do not think seriously about the complex matters involved in recent and not so recent history and all that comes with one's nation going to war. This is part of a broader trend, in which assumptions are drawn from experiments assessing small actions in often contrived situations that make for what Kihlstrom [2004] has referred to as the 'people are stupid' school of psychology (p. 348). Kihlstrom [2008] summarized this school of thought as maintaining that 'as we go about the ordinary course of everyday living, we do not think very hard about anything, and rely on biases, heuristics, and other processes that lead us into judgmental error' and that '... the evidence of irrationality consists also (of) evidence of unconscious, automatic processes' (p. 169). Typically, the people are stupid school of psychology proposes that people's decisions are emotionally driven, not based on thought or rational processes, are irrational in that they involve going against one's own interests, are irrational in that they involve being blinded by one's own interests, do not involve choice or self-determination since they are most often non-conscious and out of awareness (automaticity), and that perceptions of deliberative choices in decision making are illusory (see Kihlstrom [2008] for a discussion of the inadequacy of evidence in support of these propositions).

Space limitations permit me to list only a few examples from experiments in social and cognitive psychology (for more examples, see Turiel [2009, in press]). I have already mentioned the examples used by Eagleman [2009] of decisions involv- 
ing financial choices (studies of this sort are cited by some economists who assert that people are not rational since psychological experiments show that they make choices that go against their self-interests in maximizing benefits). Another example comes from experiments assessing predictions in gambling decisions about sporting events with point spreads, the results of which were interpreted to show that decision making is often intuitive [Simmons \& Nelson, 2006]. There is also a long line of research on cognitive dissonance that includes recent experiments in which subjects were presented with displays of high-quality products (jams, chocolates) to sample and buy at a 1-dollar discount [Iyengar \& Lepper, 2000]. More of those exposed to a small number (e.g., 6) of choices purchased the product than those exposed to a large number (e.g., 24). Being provided with too many choices, therefore, results in a lack of control due to the forces of the situation. Other examples involving preferences for cleaning products (metaphorically washing away sins [Zhong \& Liljenquist, 2006]), and evaluations of acts like eating dog meat and incest [Haidt, 2001] have been used to generalize to moral decisions - with the conclusion that moral decisions are based on intuitions and that moral reasoning is merely after-the-fact rationalization.

These types of findings are generalized to most types of decision making, including to what lay people take to involve reasoning, purposes, understandings, and choice. The findings are considered to apply to decisions about life goals, educational pathways, occupational choices, participation in society, culture and politics, and balancing self-fulfillment with considerations about the welfare and well-being of others. The findings in the research on supposedly moral evaluations are generalized to propositions of an irrational basis to people's many concerns the world over with injustices, suffering, and war and peace (for a discussion of injustices as a basis for theories of justice, see Sen [2009]). These propositions are reminiscent of behaviorists' efforts to banish from psychology the idea of consciousness [Watson, 1924], as well as constructs that refer to inner mental states, such as personality, states of mind, feelings, plans, purposes, and intentions [Skinner, 1971].

For a time, the cognitive revolution (with roots in Gestalt theories, the work of Piaget, and social psychologists like Asch, Lewin, and Heider) did change psychologists' orientations because of the recognition that people do think, along with assessments that evidence for irrationality and determinism of decisions was lacking. In spite of evidence to the contrary emanating from much research conducted in cognitive and developmental psychologies during the cognitive revolution, many have reverted to notions about irrationality and predetermined choices. As Kihlstrom [2008] put it with obvious irony: 'One is tempted to ask whether we really had a cognitive revolution in psychology for this - to learn that Skinner had it right after all, that we really are all under the control of environmental events, and all that he missed was the wiring diagram that connects stimulus with response' (p. 172). I would add that Freud, too, had it right after all and that all he missed was that the unconscious is not dynamic or conflictful.

It is important to note that the claims about irrationality are not about mistakes or errors that people make in their efforts to understand the world. Rather, it is claimed that we fool ourselves, create a mythical world, and engage in illusions; in short, we do not act with goal-directed thinking and most of the time our decisions are determined by mysterious causes (as in the title of Ariely's [2008] book, Predictably Irrational: The Hidden Forces That Shape Our Decisions). As Freud [1927/1961] noted, 'an illusion is not the same thing as an error' (p. 30). The distinction can be 
illustrated with reference to how we treat psychological theories we do not accept as valid. Whereas many psychologists would say that Freud or Skinner or Piaget (fill in your favorite examples) were mistaken in their explanations, it would not be said they were irrational or deluded. But it is claimed that the people psychologists study do not think very hard about their experiences and have illusions about most things. That is, mistakes and inadequate understandings are automatically interpreted as emotionally determined, irrational decisions.

Students of human development, who were an important part of the cognitive revolution, often examined children's mistakes, errors, and inadequate understandings of particular domains (e.g., number, mathematics, causality, the physical world, morality, psychological understandings) as means of explaining thought and development. A well-known example comes from the vast literature on theory of mind. It has been shown that young children's erroneous predictions of others' actions are consistent with their ways of reasoning about mental states. Studying the types of reasoning that leads to such errors provides a basis for explaining thought and development about psychological understandings. Developmental psychologists often realize that children's errors do not stem from a lack of thought or inattention to the world. Rather, errors reflect systematic ways of thinking in attempts to better understand the world and to more effectively act upon it. Analyses of how children arrive at their conclusions or decisions - erroneous or not - have yielded better explanations of their ways of thinking. Errors, along with eventual awareness that one has it wrong in some ways, can produce changes in thinking. Developmental research has also demonstrated that individuals form more than one system of thought in different domains and, thereby, maintain a variety of goals that can be in conflict with each other and in many contexts require coordination [Turiel, in press]. Some accounts of irrationality have examined only one realm or type of goal (e.g., maximizing benefits) without considering how different realms and goals are weighed and balanced against each other.

Students of human development, for the most part, have not been susceptible to the people are stupid school of psychology. It is no coincidence that much of the work in developmental psychology is not in accord with those who discount the relevance of thought and choice in decision making. Studying children and their development highlights how humans reason, integrate emotions and thought, and attempt to make sense of their physical, social, and emotional experiences. However, the attention currently given to irrationality and non-conscious choices makes it important for students of human development to actively engage in these debates. Developmentalists are well-placed for another revolution to reassert that humans are thinking and emotional beings in reciprocal interactions with the physical and social world. There is ample evidence from research on human development demonstrating that people form understandings of the physical world and social relationships, that such understandings stem from bidirectional, reciprocal individual-environment interactions, and that such understandings entail integration and interweaving of reasoning, emotions, and actions. The study of children and development provides a necessary corrective to the types of determinism that fails to recognize that reasoning is a hallmark of human functioning. 


\section{References}

Ariely, D. (2008). Predictably irrational: The hidden forces that shape our decisions. New York: Harper Collins.

Eagleman, D. (2009). The long and short of Obama's timetable [op-ed]. The New York Times, p. A33.

Freud, S. (1961). The future of an illusion (transl. J. Strachey). New York: Norton. (Original work published 1927.)

Gladwell, M. (2005). Blink: The power of thinking without thinking. New York: Little, Brown, and Company.

Haidt, J. (2001). The emotional dog and its rational tail: A social intuitionist approach to moral judgment. Psychological Review, 108, 814-834.

Iyengar, S.S., \& Lepper, M.R. (2000). When choice is demotivating: Can one desire too much of a good thing? Journal of Personality and Social Psychology, 79, 995-1006.

Kihlstrom, J.H. (2004). Is there a 'people are stupid' school in social psychology? Behavioral and Brain Sciences, 27, 348-349.

Kihlstrom, J.H. (2008). The automacity juggernaut - or, are we automatons after all? In J. Baer, J.C. Kaufman, \& R.F. Baumeister (Eds.), Are we free? Psychology and free will (pp. 155-180). New York: Oxford University Press.

Sen, A. (2009). The idea of justice. Cambridge: Harvard University Press.

Simmons, J.P., \& Nelson, L.D. (2006). Intuitive confidence: Choosing between intuitive and nonintuitive alternatives. Journal of Experimental Psychology - General, 135, 409-428.

Skinner, B.F. (1971). Beyond freedom and dignity. New York: Knopf.

Turiel, E. (2009). The relevance of moral epistemology and psychology for neuroscience. In P. Zelazo, M. Chandler, \& E. Crone (Eds.), Developmental social cognitive neuroscience (pp. 313-331). New York: Taylor \& Francis.

Turiel, E. (in press). The development of morality: Reasoning, emotions, and resistance. In W. Overton (Ed.), Handbook of lifespan human development. New York: Wiley.

Vedantam, S. (2010). The hidden brain: How our unconscious minds elect presidents, control markets, wage wars, and save our lives. New York: Spiegel \& Grau.

Watson, J.B. (1924). Behaviorism. New York: The People's Institute.

Zhong, C., \& Liljenquist, K. (2006). Washing away your sins: Threatened morality and physical cleansing. Science, 313, 954-958. 